\title{
African savanna elephants (Loxodonta africana) as an example of a herbivore making movement choices based on nutritional needs
}

\author{
Fiona Sach ${ }^{1,2}$, Ellen S Dierenfeld ${ }^{3,4}$, Simon C Langley-Evans ${ }^{1,2}$, Michael J Watts ${ }^{1}$, Lisa Yon ${ }^{\text {Corresp. }{ }^{1,5}}$ \\ 1 Inorganic Geochemistry, Centre for Environmental Geochemistry, British Geological Survey, Nottingham, United Kingdom \\ 2 School of Biosciences, University of Nottingham, Sutton Bonington, United Kingdom \\ 3 Ellen Dierenfeld LLC, Saint Louis, United States of America \\ 4 School of Animal, Rural \& Environmental Sciences, Nottingham Trent University, Nottingham, United Kingdom \\ 5 School of Veterinary Medicine and Science, University of Nottingham, Sutton Bonington, United Kingdom \\ Corresponding Author: Lisa Yon \\ Email address: lisa.yon@nottingham.ac.uk
}

Background. The increasing human population and global intensification of agriculture have had a major impact on the world's natural ecosystems and caused devastating effects on populations of megaherbivores such as the African savanna elephants, through habitat reduction and fragmentation and increased human-animal conflict. Animals with vast home ranges are forced into increasingly smaller geographical areas, often restricted by fencing or encroaching anthropogenic activities, resulting in huge pressures on these areas to meet the animals' resource needs. This can present a nutritional challenge and cause animals to adapt their movement patterns to meet their dietary needs for specific minerals, potentially causing human-animal conflict. The aim of this review is to consolidate understanding of nutritional drivers for animal movement, especially that of African savanna elephants, and focus the direction of future research. Peer reviewed literature available was generally geographically specific and studies conducted on isolated populations of individual species. African savanna elephants have the capacity to extensively alter the landscape and have been more greatly studied than other herbivores, making them a good example species to use for this review. Alongside this, their movement choices, potentially linked with nutritional drivers could be applicable to a range of other species. Relevant case study examples of other herbivores moving based on nutritional needs are discussed.

Methods. Three databases were searched in this review: Scopus, Web of Science, and Google Scholar, using identified search terms. Inclusion and exclusion criteria were determined and applied as required. Additional grey literature was reviewed as appropriate.

Results. Initial searches yielded 1,870 records prior to application of inclusion and exclusion criteria. A less detailed review of grey literature, and additional peer-reviewed literature which did not meet the inclusion criteria but was deemed relevant by the authors was also conducted to ensure thorough coverage of the subject.

Discussion. A review of peer reviewed literature was undertaken to examine nutritional drivers for African elephant movement, exploring documented examples from free-ranging African savanna elephants and, where relevant, other herbivore species. This could help inform prediction or mitigation of human-elephant conflict, potentially when animals move according to nutritional needs, and related drivers for this movement. In addition, appropriate grey literature was included to capture current research. 
1

2

3 Fiona Sach ${ }^{1,2}$, Ellen S Dierenfeld ${ }^{3,4}$, Simon C Langley-Evans ${ }^{1,2}$, Michael J Watts ${ }^{1}$, Lisa Yon ${ }^{1,5}$

$4{ }^{1}$ Inorganic Geochemistry, Centre for Environmental Geochemistry, British Geological Survey, 5 Nottingham, United Kingdom.

62 School of Biosciences, University of Nottingham, Sutton Bonington, United Kingdom.

$7 \quad{ }^{3}$ Ellen Dierenfeld LLC, Saint Louis, United States of America.

$8{ }^{4}$ School of Animal, Rural \& Environmental Sciences, Nottingham Trent University, Nottingham, 9 United Kingdom.

${ }^{5}$ School of Veterinary Sciences, University of Nottingham, Sutton Bonington, United Kingdom.

\section{African savanna elephants (Loxodonta africana) as an example of a herbivore making movement choices based on nutritional needs}

12

Corresponding author on final publication:

Lisa Yon ${ }^{1,5}$

${ }^{1}$ School of Veterinary Sciences, University of Nottingham, Sutton Bonington, United Kingdom.

${ }^{5}$ Inorganic Geochemistry, Centre for Environmental Geochemistry, British Geological Survey, Nicker Hill, Keyworth; Nottingham, United Kingdom.

Email address: lisa.yon@nottingham.ac.uk 
24 Abstract

25 Background.

26 The increasing human population and global intensification of agriculture have had major

27 impacts on the world's natural ecosystems and caused devastating effects on populations of

28 mega-herbivores such as the African savanna elephants, through habitat reduction and

29 fragmentation and increased human-animal conflict. Animals with vast home ranges are forced

into increasingly smaller geographical areas, often restricted by fencing or encroaching

anthropogenic activities, resulting in huge pressures on these areas to meet the animals' resource

needs. This can present a nutritional challenge and cause animals to adapt their movement

patterns to meet their dietary needs for specific minerals, potentially causing human-animal conflict.

The aim of this review is to consolidate understanding of nutritional drivers for animal movement, especially that of African savanna elephants, and focus the direction of future research. Peer-reviewed literature available was generally geographically specific and studies conducted on isolated populations of individual species. African savanna elephants have the capacity to extensively alter the landscape and have been more greatly studied than other herbivores, making them a good example species to use for this review. Alongside this, their movement choices, potentially linked with nutritional drivers could be applicable to a range of other species. Relevant case study examples of other herbivores moving based on nutritional needs are discussed.

Methods.

Three databases were searched in this review: Scopus, Web of Science, and Google Scholar, using identified search terms. Inclusion and exclusion criteria were determined and applied as required. Additional grey literature was reviewed as appropriate.

\section{Results.}

Initial searches yielded 1,870 records prior to application of inclusion and exclusion criteria. A less detailed review of grey literature, and additional peer-reviewed literature which did not meet

1 the inclusion criteria but was deemed relevant by the authors was also conducted to ensure 2 thorough coverage of the subject.

3 Discussion. A review of peer-reviewed literature was undertaken to examine nutritional drivers

54 for African elephant movement, exploring documented examples from free-ranging African 
savanna elephants and, where relevant, other herbivore species. This could help inform prediction or mitigation of human-elephant conflict, potentially when animals move according to nutritional needs, and related drivers for this movement. In addition, appropriate grey literature was included to capture current research.

\section{Introduction}

The African savanna elephant (Loxodonta africana) is categorised as vulnerable on the IUCN Red List and free-ranging populations have declined rapidly across Africa since 1970, predominantly as a result of increased poaching and competition for resources with an increasing human population (Blanc, 2008). This competition arises due to the intersection of human activities with elephants' home ranges, and much research is devoted to investigating the reasons why the animals move repeatedly through areas which lead them into conflict with humans (Eltringham, 1990; Hoare \& du Toit, 1999; Hoare, 2000). The aims of this review are to examine the current knowledge on the mineral requirements of the African savanna elephant, to consolidate the current understanding of nutritional drivers for African savanna elephant movement, to examine how geochemistry may affect herbivore movement and to consider how this knowledge could be applied to predict and mitigate human-elephant conflict in the future. African savanna elephants have the capacity to extensively alter the landscape and have been more extensively studied than other herbivores, making them a good example species to use within this review. Where relevant, examples of other herbivore movement (including other elephant species) based on nutritional needs are included.

Due to their vast food consumption and behaviour, African savanna elephants can cause significant damage to crops and vegetation (Eltringham, 1990; Hoare, 2000) and pose a risk to human life and infrastructure. Continued increase in the global human population, to 9.7 billion by 2050 , and the associated intensification of agriculture will have major impacts on the world's natural ecosystems (Nyhus, 2016). This, coupled with a predicted reduction of 200-300 million hectares of wildlife habitat worldwide, will aggravate human-animal conflict. Wide ranging landscape-level herbivores are increasingly threatened globally (Wall et al., 2013). Habitat encroachment and fragmentation poses a substantial threat to elephant populations, forcing them to condense into ever-smaller geographical areas or fenced reserves, whilst putting increased pressure on these areas to meet the animals' resource needs (Nyhus, 2016). This can present a 
86

nutritional challenge and might cause animals to adapt their movement patterns to meet their dietary needs, including for specific minerals, presenting wildlife managers with new management issues.

It is the aim of this review to consolidate understanding of nutritional drivers for animal movement especially those of the African savanna elephant, and focus the direction of future research. This will be achieved with the following objectives:

1. Examine current knowledge on mineral requirements in elephants, including the differences between the nutritional needs of cows and bulls and the activity budget of the species, including time spent feeding,

2. Examine the relationship between the geochemistry and the associated soil of an area, and how this can alter the minerals available in plants to elephants as consumers (herbivores). Use this information to examine how geochemistry may act as a driver for African savanna elephant movement. Only minerals are being considered within this review.

3. Consider how knowledge of mineral distribution in the landscape could be used to predict and mitigate human-elephant conflict in the future.

This review is intended to benefit conservation managers, ecologists, conservation biologists, national park management authorities, and potentially managers of animals under human care both within zoos and fenced reserves.

\section{Methods}

The following method was used to ensure comprehensive and unbiased coverage of the literature. Published studies were identified from three databases, using a range of search terms relating to elephant movement choices.

\section{Search terms:}

List 1: 'elephant', 'Elephantidae', 'Loxodonta', 'mega herbivore'

List 2: 'soil', 'mineral', 'minerals', 'nutrition' 'geochemistry' 'movement'

The clause 'and' was included between each word in list 1 and list 2. Each search contained 1 word from list 1 and one from list 2. Each word from each list was searched together. 
115 Search terms were selected based on a scan of the literature to give broad covering of subject of 116 interest.

117 Databases searched: Scopus, Web of Science, and Google Scholar (searched up to $1^{\text {st }}$ April 118 2018).

119 Fields searched: titles, keywords, abstracts

\section{Inclusion/exclusion criteria:}

121 Only publications which met the following criteria were included in this review. The publication:

122 1. Contained at least one of the search terms from each list in the abstract, title or keywords.

1232 . Was in a published peer-reviewed journal.

1243. Was in English.

4. Was relevant to the subject matter (e.g. excluded irrelevant terms such as elephant grass Pennisetum purpureum).

\section{Grey literature reviewed}

128 Additionally, relevant grey literature which did not meet the inclusion criteria was reviewed.

129 This was identified as follows:

130 1. Theses, books, and conference proceedings

131 2. Using internet searches of key terms and snowballing by searching the reference lists of 132 relevant literature (Sayers, 2007). Keywords were selected based on a scan of the literature, to 133 give a broad coverage of the subject of interest.

134

135

136

137

\section{Results}

Initial searches yielded 1,870 records. After applying the inclusion/exclusion criteria, 35 papers were fully reviewed, detailed in Appendix 1. Current work was generally geographically specific and conducted on isolated populations of individual species with dates ranging from 1969 to 2018. Further details of the breakdown of the literature search can be seen in Figure 1. All reviewed papers were on free-ranging African savanna elephants or other herbivore species including wildebeest (Connochaetes taurinus), zebra (Equus burchelli), roe deer (Capreolus capreolus) and black rhino (Diceros bicornis). Seventy percent of reviewed papers focused specifically on African savanna elephants, $30 \%$ of reviewed papers focused more broadly on herbivores. 
145 From the review of the grey literature, and additional peer-reviewed literature that did not meet

146 the inclusion criteria, 8 further references were identified, which consisted of five books, one

147 thesis and one short report, as detailed in Figure 1. Dates of references ranged from 1977-2012,

148 detailed in Appendix 1.

149 4. Elephant Nutritional Needs

150 Challenges of estimating elephant nutritional requirements

151 Due to the lack of knowledge on the digestive physiology of many wild animals, animal

152 nutritionists use domestic species as physiologic models when designing diets for captive exotic

153 animals. For large hindgut fermenters like elephants and rhinos, the recommendations given for

154 the domestic horse (National Research Council, 1989) have been suggested as the appropriate

155 model for most nutrients, due to the similarities in gastrointestinal tract anatomy (Clauss, Kienzle

$156 \&$ Wiesner, 2003). Therefore, when assessing published nutritional recommendations, the

157 benefits and limitations of using this model must be considered. This approach of using the

158 domestic horse model was validated for white rhinos (Ceratotherium simum) and Indian rhinos

159 (Rhinoceros unicornis) but not for black rhinos (Diceros bicornis) or any elephant species

160 (Clauss, Kienzle \& Wiesner, 2003). Clauss et al. (2007) demonstrated that black rhinos absorb

161 micronutrients in the same manner as horses, and suggested the same may apply in elephant

162 species. Despite the lack of validation, the horse has been extensively used as a model for captive 163 elephant nutritional physiology (Olson, 2004; Clauss et al., 2007; Walter, 2010) and overall, it is 164 considered a suitable model for many aspects of elephant digestion including the mechanisms by 165 which dietary supplements and dietary crude fibre content influence digestibility, calcium 166 absorption, and faecal volatile fatty acid composition. However, elephants have a faster ingesta 167 passage rate than horses, with a total gut transit time of 11-46 hours, compared to an average of 16848 hours in horses, and thus digestibility coefficients are lower for all nutrients (Bax \& 169 Sheldrick, 1963; Clauss et al., 2003). This must be factored into any comparison with domestic 170 horse recommendations and extrapolation be used with caution.

\section{Reported mineral deficiencies in captive and free-ranging elephants}

172 As the evidence for specific mineral needs for elephants (of either species) is very limited, 173 documented values for requirements of both African and Asian elephants (Elephas maximus) are 174 included for four key minerals; calcium, iodine, iron and zinc. Recommendations are often made 175 on a dry matter basis (DM; feed excluding moisture content). Because Asian elephants are held 
176 in greater numbers in captivity, there has been more research on the mineral needs of this

177 species.

\section{Calcium}

179 It has been suggested that elephants have their highest calcium demands when lactating

180 (females) followed by during periods of intensive tusk growth (Dierenfeld, 2008). Calcium

181 metabolism in elephants appears to be similar to that of domestic horses, with approximately

$18260 \%$ absorbed from the diet directly in the intestines, independent of total consumption or

183 requirement, with excess excreted in the urine (Ullrey, Crissey \& Hintz, 1997). As with other

184 mammals, elephants maintain serum calcium within a narrow range through intestinal

185 absorption, renal excretion and mobilisation of bone (Ullrey, Crissey \& Hintz, 1997; Clauss et

186 al., 2003).

187 Partington (2012), while assessing calcium intake in elephants at 14 UK zoos, determined that a

188 minimum of $0.33-0.77 \%$ DM calcium was provided in the offered diets (values represented

189 minimums as calcium provision from grass or browse forages was not included in the

190 calculations). Nonetheless, even the minimum calculated concentrations exceeded the captive

191 adult elephant maintenance recommendation of $0.3 \%$ DM calcium (Ullrey, Crissey \& Hintz,

192 1997). Similarly, diets fed to zoo elephants in 7 elephant-holding Brazilian zoos contained on

193 average $0.7 \% \mathrm{DM}$ calcium, showing that minimum recommended levels were being met

194 (Carneiro et al., 2015). Diets of semi-captive Asian elephants in India contained 0.46-0.58\% DM

195 calcium (Das et al., 2015) further supporting the conclusion that calcium deficiencies have rarely

196 been documented in healthy adult captive elephants on maintenance diets. There is, however,

197 evidence that incidence of calcium deficiency is higher in cows during partition and lactation,

198 when calcium demand is increased (van der Kolk et al., 2008). Sub-clinical hypocalcaemia was

199 reported in Asian elephants immediately prior to partition at Rotterdam Zoo when calcium

200 demand was not met through dietary provision (van der Kolk et al., 2008).

201 Metabolic bone disease (rickets) was reported in captive hand-reared Asian elephant calves. This

202 disease results from an imbalance in the calcium to phosphorus ratio or from intestinal

203 malabsorption, and unbalanced milk formulation may have played a role in this case (Ensley et

204 al., 1994). 
205 Iodine

206 The thyroid mass of an elephant relative to its body mass is double its predicted size, compared

207 to other mammals (Milewski, 2000). This may indicate that the iodine requirements of elephants

208 are proportionally higher than those of other herbivores, and that due to the exclusively

209 herbivorous diet of elephants, they may be susceptible to iodine deficiency (Milewski, 2000).

210 Due to the lack of essentiality of iodine to plant metabolism, land plants have little reason to

211 translocate iodine from soil to foliage, therefore plants consumed by elephants may be low to

212 deficient in iodine (Shetaya et al., 2012; Humphrey et al., 2018). Soil dust deposition has been

213 documented to increase iodine levels of foliage in some situations (Watts et al., 2015). As an

214 alternative iodine source, elephants may seek iodine supplementation from iodine rich water or

215 soil (via geophagy). Humans in Malawi were able to obtain as much as $70 \%$ of daily iodine

216 requirements from drinking two litres of borehole water per day (Watts et al., 2015). Iodine is

217 required for reproduction, and the high reproductive success of elephants in conservation areas

218 such as Addo Elephant Park, which contained several boreholes, was hypothesised to be linked

219 with an increased supply of iodine (Milewski, 2000; Milewski \& Dierenfeld, 2012).

220 In the Kitum caves, Mount Elgon, Kenya, elephants consume the cave salts that correlate with

221 high levels of calcium, sodium, magnesium and phosphorus (Bowell, Warren \& Redmond,

222 1996). Iodine was measured in the salt crusts at $1,149 \mathrm{mg} / \mathrm{kg}$, which was $>100$ times higher than

223 iodine concentrations in the most iodine-rich soils in the vicinity. Reproductive outputs of

224 elephant populations consuming these minerals were also high (Bowell, Warren \& Redmond,

225 1996). Given these various lines of inferential evidence, supply or restriction of iodine-rich bore

226 holes could be further investigated as an effective method of population control in situ, without

227 affecting reproductive success of smaller herbivores that may have a proportionally lower

228 requirements for iodine, which could be realised by diet, water or geophagy (Milewski, 2000;

229 Milewski \& Dierenfeld, 2012).

230 Iron

231 Iron deficiency anaemia has rarely been reported in captive or free-ranging elephants, although

232 several cases of anaemia linked with liver fluke infection, retained placenta, tuberculosis,

233 tuberculosis treatment and malabsorption syndrome have been documented (Dierenfeld, 2008).

234 Only a single reported iron deficiency anaemia related to low dietary iron intake, affecting three

235 newly imported Asian elephants, was documented. In this case, clinical signs resolved upon 
236 dietary supplementation (Kuntze \& Hunsdorff, 1978). Diets of semi-captive Asian elephants

237 contained 105-126 mg iron/kg DM (Das et al., 2015), considerably in excess of the Nutrition

238 Advisory group recommendation of $50 \mathrm{mg}$ iron/kg DM (Ullrey, Crissey \& Hintz, 1997; Das et

239 al., 2015).

240 Zinc

241 The dietary recommendation for zinc in captive elephants is $40 \mathrm{mg} / \mathrm{kg} \mathrm{DM}$ diet, based on

242 determined requirements of domestic horses (Olson, 2004; Ullrey et al. 1997). Partington (2012)

243 reported zinc levels of between 22 and $52 \mathrm{mg} / \mathrm{kg}$ DM in zoo elephant diets offered in $14 \mathrm{UK}$

244 facilities. However, this figure does not account for zinc provision from grass and/or browse

245 forages, which comprise the majority of the diets, hence these data are limited. Nonetheless the

246 lower end values suggest that some animals may have been consuming inadequate levels of

247 dietary zinc. Semi-captive Asian elephants in India were reported to consume diets containing

248 levels of zinc between 38.4 to $45.9 \mathrm{mg} / \mathrm{kg}$ DM (Das et al., 2015); no clinical signs of deficiency

249 were seen and serum concentrations were within the ranges reported for healthy elephants

250 (Ullrey, Crissey \& Hintz, 1997; Das et al., 2015). Excess dietary calcium was observed to

251 interfere with zinc bioavailability resulting in skin abnormalities in a zoo elephant (Schmidt,

252 1989; Dierenfeld, 2008). Schmidt (1989) reported a case of zinc deficiency in a captive Asian

253 elephant, resulting in secondary immune deficiency and skin lesions. The dietary zinc level in

254 that individual was increased from 22 to $54 \mathrm{mg} / \mathrm{kg} \mathrm{DM}$ and significant clinical improvement was

255 seen within two weeks, with lesions resolved after 8 weeks.

256 Together, these observations confirm that the domestic horse may indeed provide a suitable

257 physiologic model for mineral nutrition of elephants.

\section{African savanna elephant feeding behaviour}

260

African savanna elephants (Loxodonta africana) consume a variety of plant material including

261

grasses, leaves, twigs, fruits, barks, herbaceous material and soil (Kabigumila, 1993; Dierenfeld, 2008). Although described as generalist herbivores consuming over 400 species of plants, diet composition may vary regionally and seasonally (Kabigumila, 1993). African savanna elephants are predominantly seasonal grazers and browsers with fruit, barks and soil being consumed as secondary food choices (Kabigumila, 1993). There is debate as to whether savanna elephants are 
266 predominantly grazers or browsers, with evidence supporting both feeding strategies:

267 Williamson (1975) reported elephant diets in Hwange National Park, Zimbabwe to consist 268 almost entirely of woody plants whereas Wing and Buss (1970) reported that elephants in

269 Uganda relied primarily on grasses (approximately $90 \%$ of bulk) and therefore labelled the

270 species as grazers. Such geographical variations in diet have prompted some authors to classify

271 elephants as browsers (Jachmann \& Bell, 1985), whereas others maintain they are primarily

272 grazers (Beekman \& Prins, 1989; Tangley, 1997). Therefore it is thought that savanna elephants

273 adopt both feeding strategies, and switch depending on environment and season.

274

275 Several studies indicate that savanna elephants spend over half of their daily time budget

276 feeding. Elephants in Tsavo National Park, Kenya were observed to feed for 48-63\% of daylight

277 hours (Dougall \& Sheldrick, 1964) and elephants in Lake Manyara National Park, Tanzania were

278 observed to spend on average $76 \%$ of daylight hours feeding (Beekman \& Prins, 1989). Where

279 feeding conditions improved and food availability increased, Guy (1975) observed elephants in

280 Zimbabwe to reduce the total amount of time spent feeding to 50-60\% of overall time budget,

281 from a greater proportion of their time budget when food resources were limited. Likewise,

282 savanna elephants in areas of food scarcity in Uganda were reported by Beekman and Prins

283 (1989) to spend as much as $74 \%$ of their total time budget feeding. Flexibility in food items

284 consumed and time spent feeding, indicated that elephants respond and adapt their feeding

285 strategy according to varying availability of food resources.

286 Savanna elephants have been documented to feed throughout the day, with decreased feeding

287 and increased resting during the middle part of the day; 12:00-14:00 hrs (Laws, 1970; Beekman

288 \& Prins, 1989; Shannon et al., 2008). This pattern was observed in both sexes. Seasonally, the

289 total amount of time spent feeding per day has not been documented to change, although

290 elephants were observed by Shannon et al. (2008) to adjust the time of day spent feeding in the

291 hotter summer months. Evidence suggests that plant selection and feeding strategy changes

292 depending upon availability. During the wet season elephants were observed by Beekman and

293 Prins (1989) to spend 67\% of time grazing with $8 \%$ browsing, whilst during the dry season

294 proportions shifted to $23 \%$ of time grazing and $60 \%$ browsing. During the dry season, the protein

295 content of the grasses decreased. When the protein content of the grasses dropped to $<2.5 \%$,

296 elephants in Tanzania were seen by Barnes (1982) to increase their browse consumption. Browse 
297 typically contains higher levels of secondary compounds such as tannins than grass (Ellis, 1990)

298 and thus, as a by-product of this intensified browse consumption during the dry season, tannin 299 and associated levels of toxin accumulation were seen to increase (Barnes, 1982).

300 Mineral levels in plants vary seasonally, geographically and between different parts of the plant

301 (Joy et al., 2015) (Table 1 provides specific examples). Due to the generalist feeding nature of

302 African savanna elephants, it is thought that they are able to adapt their food selection as 303 required to meet their target levels of (as yet undetermined) mineral requirements (Bax \& 304 Sheldrick, 1963). This was demonstrated in elephants within the Kruger National Park (KNP),

305 South Africa, where there is substantial geographical and seasonal variation in plant types 306 consumed by elephants (Codron et al., 2006). Stable carbon isotope analysis of faecal material 307 indicated that during the dry season, elephants in northern KNP consumed significantly more 308 grass than their southern counterparts; $40 \%$ of their diet was grass in the northern part of the park 309 during the dry season, compared to just $10 \%$ in southern KNP (Codron et al., 2006). In contrast, this difference in grass consumption between elephants in the northern and southern parts of this national park was not apparent during the wet season, when elephants throughout the park consumed grass at approximately $50 \%$ of their overall diet (Codron et al., 2006). This is in accordance of the observed trend of increased grass consumption during the wet season (Beekman and Prins, 1989). Although elephants consume a vast number of different plant species, they generally receive the bulk of their diet from a few selected species which vary seasonally and geographically (Meissner et al., 1990; Kabigumila, 1993). Bax and Sheldrick (1963) observed elephants in the Tsavo National Park, Kenya, to select specific plant parts, notably bark rich in calcium.

319 Free-ranging African savannah elephant daily food intake is estimated from either the weight of the stomach contents (post mortem) or from extrapolation of data on feeding rates and time spent feeding. Both methods have produced similar estimates of daily dry matter intake for adults of about 1.0-1.5\% of body weight (Meissner et al., 1990; de Villiers et al., 1991; Ullrey, Crissey \& Hintz, 1997). Dry matter intake relative to body weight is influenced by a number of factors: dry matter digestibility, environmental stressors, activity levels and life stage of the animal (adult maintenance, growth, pregnancy or lactation) (Meissner et al., 1990). Laws (1970) concluded that non-pregnant females and males consumed 1.0-1.2\% BW DM (percentage of body weight 
327 on a dry matter basis whereas pregnant females consumed 1.2-1.5\% BW DM. On an as-fed basis

328 (feed including moisture content) elephants consumed about 4\% of their body weight per day

329 (Laws 1970).

330 Evidence shows differences between elephant bulls and reproductively active cows in their

331 nutritional needs and associated diet choices, with cows possibly requiring higher levels of

332 minerals and protein to support growing calves (Dierenfeld, 2008). Greyling (2004) documented

333 that in the Associated Private Nature Reserves (APNR), South Africa, there was a nutritional

334 difference between various parts of the plants consumed by savanna elephants, with leaves

335 containing more calcium and phosphorus than twigs. It is therefore suggested that cows and bulls

336 meet their differing nutritional needs primarily through plant part selection. Family groups with

337 pregnant and lactating females consumed proportionally more leaves and bark in their diet

338 compared to bulls. In the dry season, females consumed 3\% leaves and 14\% bark, whereas males

339 consumed 1\% leaves and 6\% bark and additional twigs (Greyling, 2004). This agreed with the

340 previous work of Stokke and DuToit (2002), who found that bulls consumed more twigs than

341 cows, and cows engaged in more leaf stripping than bulls.

342 Greyling (2004) also documented bulls to consume more plant species with a higher calcium

343 content than adult cows at maintenance (without calves) throughout the year. Greyling suggested

344 that such mineral selectivity may be due to a higher calcium requirement for tusk growth in

345 males compared to females at maintenance. This observation supports previous work conducted

346 by McCullagh (1969) who suggested a calcium requirement for male elephants of 8-9 g/day.

347 Additionally, lactating females were found to have significantly higher calcium needs than adult

348 females at maintenance, as summarised in Table 2.

349 During the dry season, Greyling (2004) found bull faeces contained significantly lower

350 phosphorus levels than faeces of cows in family groups. On average, cow faecal samples

351 contained 18\% more phosphorus than bulls. Faecal phosphorus levels have been used in

352 agriculture to estimate dietary phosphorus in livestock, and they are a more reliable index to diet

353 quality than faecal nitrogen as they are not influenced by tannins (Holechek et al., 1985; Wu,

354 Satter \& Sojo, 2000). Lower faecal phosphorus in bulls suggests that less phosphorus was

355 consumed in the diet, which might indicate that the requirement for bulls was lower than that of

356 cows (Grant, Meissner \& Schultheiss, 1995; Wrench, Meissner \& Grant, 1997). 
357 Feeding time budgets of populations of both sexes, studied in three reserves in South Africa, 358 were found to be similar (Shannon et al. 2008). This suggests that cows obtained the required

359

360

361

362

363

364

365

366

367

368

369

370

371

372

373

374

375

376

377

378

379

380

381

382

383

384

385

386

increased dietary energy for pregnancy or lactation, by altering plant selection to preferentially select more energy dense plants, rather than by increasing time spent feeding (Shannon et al., 2008). This finding contradicts that of Guy (1975), who concluded that bulls consumed more 'trunk fulls' of plant material per minute than cows, especially during the dry season, and bulls stayed for longer at feeding sites than family groups (Stokke \& Du Toit, 2002). Stomach fill post mortem of non-pregnant or lactating females and males was smaller than that of pregnant and lactating females, suggesting that females increased their overall food consumption to meet the nutritional demands of pregnancy and lactation (Laws, 1975). These pieces of mixed evidence suggest that several feeding strategies may be adopted by elephant cows and bulls to meet their specific individual nutritional needs, depending upon the unique environments in which they live, and seasonal resources available to them.

Documented literature on specific mineral needs in elephants is very limited and requirements per se have not been experimentally determined (Das et al., 2015). Table 2 documents minerals for which estimates have been recorded for African elephants directly. As these values were reached from various different studies, on different populations (captive and free-ranging), parameters of measurement were different e.g. grams required per day compared to mg required per kg dry matter intake or body weight of the animal. This table does not include requirements extrapolated from domestic horses.

\section{Elephant movement patters, as related to geochemistry/nutritional factors}

The availability of minerals to the plant from the soil underpins the relationship between herbivores and their food supply. The distribution of vegetation was suggested to be strongly associated with the geomorphology of the soil (Lawson, Jenik \& Armstrong Mensah, 1968; Bell, 1982). Generally plants will reflect the soil profile and those growing in mineral deficient areas will lack key minerals, thus potentially resulting in deficiencies in the consumer. In contrast, those growing in mineral abundant areas will reflect this, and pass the mineral abundance on to the consumer organism (Hurst et al., 2013; Joy et al., 2015). The ability of an area to supply minerals to an animal does not solely depend on the mineral status of the soil and geochemical parameters (such as organic matter and soil $\mathrm{pH}$ ), but also on the ability of the plant to incorporate 
387 the minerals (Bowell \& Ansah, 1994). Additional factors affect the mineral levels within a plant:

388 the pathway of nutrients from the soil to the plant depends upon the amount of element present, 389 the various soil factors that affect the minerals' bioavailability and the plant factors which 390 determine the rate of uptake of the mineral (Maskall \& Thornton, 1996).

391 Soil factors which affect a mineral's soil-to-plant transfer include the composition of the parent 392 material, quantity and composition of organic matter and the soil pH (Hurst et al., 2013). The 393 relationship between mineral status of the soil and parent rock was strongest where there was 394 minimal chemical weathering (Bowell \& Ansah, 1994). Organic matter also affects 395 bioavailability, especially that of iodine (Shetaya et al., 2012; Humphrey et al., 2018). Soil pH 396 greatly influences the metal availability (Maskall \& Thornton, 1996); in alkali soils, generally 397 the bioavailability of molybdenum and selenium increases, whilst that of copper, cobalt and 398 nickel decreases (Sutton, Maskall \& Thornton, 2002). Further, increased availability of 399 phosphorus in alkaline soil contributes to its enhanced uptake into the plant (Maskall \& 400 Thornton, 1996; Sutton, Maskall \& Thornton, 2002).

401 Plant factors affecting rate of uptake of a mineral include: age of the plant (with levels of trace 402 elements decreasing in older plants), rate of plant growth (with rapidly growing plants displaying 403 reduced levels of trace elements), and plant species (with differences seen between levels of 404 trace elements in different plant species grown in the same soil (Maskall \& Thornton, 1996). The 405 greatest differences in mineral content were reported between grasses and browses (Gomide et 406 al., 1969; Ben-Shahar \& Coe, 1992). Seasonally, trace element levels were reported to be higher 407 in plants in the wet season: in the grazing pastures in the Kenyan highlands (Howard \& Burder, 408 1962), in grasses by Lake Nakuru in the Rift Valley (Maskall \& Thornton, 1991) and in the Mole 409 National Park, Ghana (Bowell \& Ansah, 1994). Finally grazing status of the plant was seen to 410 influence plant mineral levels, with increased mineral concentrations of up to $300 \%$ in grazed 411 areas, notably sodium, phosphorus and calcium, compared to ungrazed areas supporting low 412 animal densities (McNaughton, 1988).

413 Forage mineral analysis data is routinely used to assess mineral levels in agriculture, and despite 414 its limitations, it is believed to be a reliable index to be used to assess the general ability of 415 forages to meet animals' mineral needs (McNaughton, 1988; Nellemann, Moe \& Rutina, 2002). 416 However, the mineral profile of the soil can be depleted by soil, plant, topography and weather 
417 factors. In the Sabi Sands Reserve, South Africa, 10 species of grass were analysed and grasses

418 from soils of higher mineral levels accumulated lower mineral concentrations, compared to 419 grasses from soils where the minerals were found in lower levels (Ben-Shahar \& Coe, 1992). In 420 this case, this was thought to be due to sampled species attributes, and the effect of the local 421 micro-climate on the plants.

\section{Movement choices of elephants}

423 Several studies concluded that elephant habitat use is not random, but that elephants have 424 specific preferences for various habitats and move to fulfill their resource needs (Whitehouse \& 425 Schoeman, 2003; Osborn, 2004; Douglas-Hamilton, Krink \& Vollrath, 2005; Dolmia et al., 426 2007; Thomas, Holland \& Minot, 2008; Leggett, 2015). There are a myriad of factors that 427 contribute towards elephants' movement choices including availability of food and water, 428 opportunity for social interaction, human presence and associated activities. Hydrology and 429 topography may also influence animal movement (Bowell \& Ansah, 1994; Wall, Douglas430 Hamilton \&Vollrath, 2006). Elephants tend to avoid steep slopes due to the increased energy 431 expenditure required to climb them; even minor hills can be considerable energy barriers to an elephant (Wall, Douglas-Hamilton \&Vollrath, 2006). De Knegt et al. (2011) suggested that daily movement of elephants related predominantly to food availability, and movements become extended by the distance traversed to water sources. Elephants in that study area of the KNP, South Africa concentrated their foraging within areas of high forage availability that were closest to water, whilst still being large enough areas to optimise efficiency of movement and foraging.

The significance of the impact of human activity on the natural movements of elephants is rapidly increasing (Nyhus, 2016). Tucker et al. (2018) concluded that in areas with a high level of human presence, mammal movement decreased by $35-50 \%$ across 57 species, compared with areas of low human presence. Over the last 150 years, expansion of human settlement into elephant habitat, and an increase in elephant killing (from poaching and hunting) has significantly altered elephants' home ranges across continental Africa (Eltringham, 1990; Hoare, 2000; Osborn, 2004; Nyhus, 2016). Initially it was thought that a simple linear relationship would exist between rising human and declining elephant densities at a national or subcontinental scale (Hoare \& du Toit, 1999). However, Hoare and du Toit (1999) found that in an area of $15,000 \mathrm{~km}^{2}$ in northwest Zimbabwe, the relationship turned out to be more complex. 
447 Using data from human populations, and observed elephant densities in the region, the authors

448 determined that there was a threshold beyond which elephant and human coexistence could no 449 longer occur, and elephant populations rapidly declined. This threshold was related to 450 agricultural development, and was reached when land was spatially dominated by agricultural 451 use, and the original woodland (that constituted the elephants' habitat) became sub-dominant.

452 When analysing elephant movement, water availability must be taken into account; elephants are 453 obligate drinkers (Wall et al., 2013). Water availability is considered to affect elephant 454 movement, both on a daily and seasonal basis and may be a greater driver for elephant 455 movement than mineral availability. Three studies conducted in South Africa and Kenya 456 indicated that elephant movement increased throughout the wet season when water availability 457 was greatest, and then rapidly decreased throughout the dry season, with elephants, especially 458 lactating females, confining themselves to areas within 1-2 days' travel from water to enable 459 them to conserve energy (Western \& Lindsay, 1984; Codron et al., 2006; Thomas, Holland \& 460 Minot, 2008; Birkett et al., 2012).

461 Pretorius et al. (2011) concluded that elephants made movement choices based on nutritional 462 provision in a specific area. Fertiliser was applied to mopane trees (Colophospermum mopane) in 463 the APNR, South Africa, in various patches, resulting in an increase in the phosphorus and 464 nitrogen levels in mopane leaves. Elephants consumed more mopane leaves per patch in 465 fertilised patches compared to unfertilised patches, regardless of patch size. Furthermore at a 100 $466 \mathrm{~m}^{2}$ patch size scale, elephants stripped leaves more in fertilised than unfertilised patches, but 467 were more likely to tree kill (through uprooting or breaking main trunks) in unfertilised patches. 468 Therefore, it was suggested that elephants caused more impact to trees of lower value (through 469 tree killing) whilst preserving trees of higher value (fertilised mopane) through coppicing 470 (Pretorius et al. 2011).

471 Secondly Pretorius et al. (2012) suggested that phosphorus may be a key driver for elephant 472 movement, with elephants moving throughout the year to maximise intake of this mineral. In this 473 study area in the APNR, there was a suspected local deficiency in phosphorus, potentially 474 explaining why the elephants prioritised obtaining this mineral. During the wet season, when 475 food availability was greatest, nitrogen provision was prioritised, possibly to meet the elephants' 476 needs for growth and reproduction. During the dry season, when food was potentially limited, 
477 energy was prioritised by the elephants. This could be because energy costs to obtain food and

478 water during the dry season were often higher as elephants had to travel further, due to a reduced

479 abundance of forage and availability of water (Pretorius et al., 2012).

480 Nutritional factors affecting elephant movement

481 Minerals can be provided to elephants from multiple sources, including plants, water or soil

482 (through geophagy). Examples of mineral provision from plants include sodium, calcium,

483

484

485

486

487

488

489

490

491

492

493

494

495

496

497

498

499

500

501

502

503

504

505

506

507

magnesium and phosphorus. Forest elephants (Loxodonta cyclotis) in the Kibale National Park, Uganda, were reported by Rode et al. (2006) to be crop raiding to meet their sodium need. It was reported in the literature that minerals such as copper and sodium, rather than energy and/or protein, were limited in the elephants' wild food plants, and were found in higher concentrations in crops. Often, wild elephant food plants which are high in sodium are also high in secondary compounds (Rode et al., 2006), which might inhibit the uptake of essential minerals and increase sodium excretion, and thus may further exacerbate low sodium intake (Jachmann, 1989). Crops contained lower levels of secondary compounds compared to wild plants, which allowed the elephants to resolve the complexities of meeting sodium needs without interference from secondary compounds. For example, the highest sodium-concentration wild plant in this study, Uvariopsis congensis also contained high levels of secondary compounds, saponin and had a high alkaloid score (Jachmann, 1989). Jachmann (1989) has also reported examples of elephant populations in the Miombo biome, Africa, making plant choices to create diets that contained high sodium and digestible sugar concentrations, and low concentrations of indigestible fibre and secondary compounds. The elephants especially avoided plants with high phenol and steroidal saponin levels. Additionally in Kibale National Park, seasonal availability of wild food was not correlated to the timing of crop-raiding events (Chiyo et al., 2005). This suggests that elephants may be selecting specific food crops due to their nutritional provision, rather than just being attracted to the presence of food crops and increased overall availability of food (Chiyo et al., 2005).

Finally, savanna elephants within the Mount Elgon region, Kenya, consumed salt deposits within the Kitum caves, which are rich in a variety of minerals including calcium, sodium, magnesium and phosphorus (Bowell, Warren \& Redmond, 1996). Cases of uneven tusk wear were noted and presumed to result from the use of tusks to scrape salts from the ceiling and walls (Bowell, 
508 Warren \& Redmond, 1996). The environment within the cave can be warmer at $13.5^{\circ} \mathrm{C}$ than

509 surrounding areas where night temperature can drop to $8^{\circ} \mathrm{C}$, and although this could be

510 encouraging the elephants to remain in the area overnight, it was suggested that there exists a

511 nutritional drive causing them to seek out and consume the salt deposits on the rocks (Bowell,

512 Warren \& Redmond, 1996).

513

514 Minerals can also be provided to elephants through drinking water. Sienne, Buckwal and

515 Wittemyer (2014) investigated elephant use of bais (natural forest clearings which often have

516 seasonal or year round sources of water present as surface waters) in the central African

517 rainforest and concluded that mineral provision from water is likely to be attracting elephants to

518 specific bais. Mineral concentrations in water from elephant-evacuated pits were higher than in

519 surface water, and thought to be a causative factor behind bai visitation choice. In particular

520 iodine, sodium, sulphur and zinc were elevated, while calcium, magnesium, manganese, iron and

521 tin concentrations were at least ten times higher in elephant-evacuated water compared to surface

522 waters. Blake (2002) observed that elephants congregated around bais during the dry season,

523 correlating with a seasonal peak in mineral levels in pit water, which may be due to the seasonal

524 ebbing of spring water flow. Likewise, savanna elephants in the Hwange National Park,

525 Zimbabwe were recorded by Weir (1972) in greater numbers surrounding water sources with

526 higher sodium content. Pans of high sodium water were reported to have three times as many

527 elephants when censured, compared to the lowest sodium areas, indicating that elephants might

528 make movement choices based upon sodium need (Weir 1972).

529 Finally geophagy appears to be a normal behaviour of all elephant species in the majority of

530 habitats and is thought to aid elephants in meeting their nutritional (mineral) needs (Holdø,

531 Dudley and McDowell, 2002). There is some evidence that elephants also conduct geophagy to

532 support detoxification of unpalatable secondary compounds in their diet (Mwangi, Milewski \&

533 Wahungu, 2004; Chandrajith et al., 2009). In other ungulate species, clay may decrease the

534 harmful effects of secondary plant compounds and intestinal infections (Klaus \& Schmidg, 1998;

535 Ayotte et al., 2006). Soil is never consumed randomly within an elephants' home range, but

536 instead it is consumed from specific spatially circumscribed sites (Klaus \& Schmidg, 1998). It is

537 thought that elephants principally consume soil(s) at specialised licks to supplement sodium

538 intake, although calcium, magnesium and potassium are also often higher in lick soils compared 
539 to the surrounding soils (Holdø, Dudley \& McDowell, 2002). Additionally elephants are known

540 to consume soil on termite mounds, although it remains unclear as to the driving mineral(s)

541 behind this behaviour. In contrast to the situation at lick sites, sodium levels do not seem to be

542 persistently higher in termite mounds than surrounding soils (Holdø \& McDowell, 2004).

543 A further example of geophagy by elephants was reported by Mwangi, Milewski \& Wahungu

544 (2004) in the Aberdares National Park, central Kenya, where elephants rely on browse and

545 unripe fruits to make up the majority of their diet due to a limited availability of grasses. Browse,

546 unripe fruits and seeds generally contain more tannins and alkaloids than grasses, suggesting that

547 the elephants in this national park consume more potentially harmful substances compared to

548 elephants that consume higher levels of grasses. As hindgut fermenters, neutralisation of these

549 harmful substances is not possible in the same way as it is for ruminants (where foregut

550 fermentation is used to neutralise these harmful substances). Since the soils consumed also

551 contained higher levels of sodium and iodine than surrounding soils, it is not possible to identify

552 if minerals or clays are the driving force behind this geophagic behaviour, however it was

553 considered that both factors were important (Mwangi, Milewski \& Wahungu, 2004).

554 In the Kalahari-sand region of Hwange National Park, elephants consumed high-sodium lick

555 soils during the dry season possibly in response to an unmet requirement for sodium (Holdø,

556 Dudley \& McDowell, 2002). Lactating and pregnant females consumed more soil per visit to a

557 high sodium lick than males (Holdø, Dudley \& McDowell, 2002). The latter might be due to

558 their increased requirement for sodium during pregnancy and lactation (Michell, 1995). This

559 suggests that there is a physiological cause for this geophagy and that in these cases, lick use is

560 driven by a nutritional need. Female elephants will increase geophagy to meet their additional

561 nutritional needs during pregnancy and lactation (Michell, 1995). Table 1 documents sodium

562 levels in browse species during the dry season that are lower than during the wet season, and

563 were suggested by Holdø Dudley \& McDowell (2002) to be insufficient. The soil in the mineral

564 lick areas also contained elevated levels of magnesium and calcium, however, these minerals

565 were also available in adequate amounts from other sources such as termite mounds or dietary

566 browse. Interestingly, consumptions of termite mound soils was not observed. Therefore the

567 authors concluded that these elephants were conducting geophagy based on sodium need (Holdø,

568 Dudley \& McDowell, 2002). 
570 As well as the increased clay in the soil in the Aberdares National Park, Mwangi, Milewski and

571 Wahungu (2004) found that the soil consumed by the elephants also contained higher levels of

572 sodium and iodine than the surrounding areas, but was significantly lower in zinc, manganese

573 and iron levels. Additionally, there was 250\% more phosphorus and 50\% more magnesium in the

574 consumed soil than the surrounding control soil (Mwangi, Milewski \& Wahungu, 2004). This

575 suggests that elephants of this population chose to consume soil in certain areas based on

576 nutrition provision, and that specific minerals were prioritised.

577

578 There is debate as to whether elephants alter their movements to seek out and consume either the

579 soil from termite mounds, or plant material growing on the termite mounds, to meet their mineral

580 needs (Holdø \& McDowell, 2004; Muvengwi, Mbiba \& Nyenda, 2013; Muvengwi et al., 2014).

581 Soil from termite mounds includes both surface soil and deeper subsoil, raised to the surface by

582 termites. Previous studies generally focused on one geographical area and thus results may be

583 geographically specific depending upon surrounding mineral availability. It appears to be

584 universally acknowledged that soils from termite mounds contain more minerals than

585 surrounding areas as the termites mine deeply into the substrate (Holdø \& McDowell, 2004;

586 Muvengwi, Mbiba \& Nyenda, 2013; Muvengwi et al., 2014). However, the evidence as to

587 whether elephants move to seek and consume specific soils (and plants) for targeted minerals is

588 variable. Muvengwi, Mbiba \& Nyenda (2013) showed that tree diversity did not vary

589 significantly on termite mounds or control plots, in Chewore North, Zimbabwe, yet net biomass

590 removal by mega-herbivores was up to five times higher on control plots than termite mounds.

591 Specifically when measuring consumption of Colophospermum mopane, there was no difference

592 in biomass removal between termite mounds and control plots (Muvengwi et al., 2014).

593 In contrast, black rhino in Chipinge Safari, Zimbabwe, were observed to browse on foliage

594 growing on termite mounds more than off termite mounds, seen by increased bite intensity on the 595 plants from the termite mounds (Muvengwi et al., 2014). This is suspected to be due to the 596 increased soil and foliar mineral levels. Concentrations of nitrogen, potassium, phosphorus,

597 calcium and sodium were found to be approximately double in the soil and leaves on termite 598 mounds, compared to those off the termite mounds (Muvengwi et al., 2014). In the Kalahari 
599 Sand Hwange National Park, Zimbabwe elephants consumed soil from the high sodium, sparsely 600 grassed areas on top of the termite mounds if the surrounding soil had a low concentration of 601 sodium, but not if the surrounding soil areas had comparably higher sodium content (Weir, 602 1969). In western Zimbabwe, 12 paired sample sites were compared. Each site consisted of an 603 area with a termite mound and a corresponding area within woodland, containing no termite 604 mound. Holdø and McDowell (2004) concluded that although the soils within the termite 605 mounds contained more of all tested minerals, the plants on the termite mounds contained less 606 sodium than the plants in woodland plots. Elephants fed more intensively from the plants on the 607 termite mounds than within the woodlands indicating that in this situation, the animals were 608 probably seeking other minerals in addition to sodium from the termite mounds (Holdø \& 609 McDowell, 2004).

610 Finally, termite mounds which are consumed by elephants within the Mimbo ecosystem of the 611 Ugalla Game reserve, Tanzania, contained more minerals than termite mounds which are not 612 used for geophagy (Kalumanga, Mpanduji \& Cousins, 2017). Amounts of each mineral 613 correlated with each other, making it impossible to distinguish a single versus multiple specific 614 driver(s) underlying geophagy. However, it is clear that mineral-rich termite mounds are being 615 selected for consumption over less mineral-rich termite mounds (Kalumanga, Mpanduji \& 616 Cousins, 2017). Human-elephant conflict is caused when elephants make forays into human settlement resulting in some form of damage. Humans retaliate to injure, kill or displace the elephant (Hoare, 2000). The African Elephant Specialist Group (AfESG) conducted an inventory of sites across Africa where HEC occurs. It was concluded that the issue is widespread and HEC occurs where interactions happen between the home range of elephants and human activity. Approximately $20 \%$ of elephant home range is within legally protected areas however, conflict was documented

625 to occur in both protected and non-protected areas (Said et al., 1995). Crop losses attributed to 626 elephants across Africa was low (5-10\%), and elephants were considered to be low on the list of 627 agricultural pests (Hoare, 2000; Naughton-Treves, 2008). However, wide spread low level 
628 damage from non-dangerous crop pests were better tolerated by communities than rare, localised

629 catastrophic damage caused by elephants (Said et al., 1995; Hoare, 2000; Naughton-Treves,

630 2008). There is limited evidence to support the relationship between problems caused by

631 elephants and the level of elephant density or nutritional food limitation (Barnes, Asika \&

632 Asamoah-Boateng, 1995; Hoare, 1999). The optimum foraging theory has been suggested to

633 explain the unpredictable nature of crop raiding across the savanna (Hoare, 1999). This theory

634 predicts that animals will maximise the quality of nutrient intake where possible and thus when

635 crops of higher nutritional value than wild food plants are available, animals will prioritise

636 consumption over their normal food crops (Begon, Harper \& Townsend, 1986).

637

638

639

640

641

642

643

644

645

646

647

648

649

650

651

652

653

654

655

656

657

\section{Applications to other herbivore species in comparable environments}

Consideration of geochemistry is required for maintenance of healthy animal populations, especially within fenced reserves where animal migration is impossible. For example, in Lake Nakuru National Park, Kenya which is a fenced area of $160 \mathrm{~km}^{2}$, the soil is derived from volcanic ash, pumice and lake sediment, with low levels of extractable cobalt, copper and acetic acid with a high alkaline soil pH (Maskall \& Thornton, 1996). In this region of the Rift Valley, mineral deficiencies including copper and cobalt were seen in domestic cattle, as well as in impala (Aepyceros melampus) and waterbuck (Kobus defass) (Maskall \& Thornton, 1996). The increased soil $\mathrm{pH}$ caused increased uptake of molybdenum by the plants, which in turn inhibited the utilisation of copper in ruminant animals, further exacerbating the deficiency of copper (Underwood, 1977). A geochemical survey was conducted and results of this related to observed clinical copper deficiencies in animals (Maskall \& Thornton, 1996). Following this investigation, recommendations were made to the Kenya Department of Wildlife Conservation and Management that mineral salts containing cobalt, copper and selenium should be made available to wildlife in the park to mitigate these mineral deficiencies (Thornton, 2002). Due to the physiological differences in mechanisms of copper absorption in ruminants and non-ruminants, elephants are not as sensitive to this deficiency as ruminant species and a similar problem has not been documented in elephants (Maskall \& Thornton, 1996).

Clinically observed copper deficiencies caused by an increased uptake of molybdenum by the plant and thus interference in the utilisation of copper by the animal were seen in Grant's gazelle (Gazelle granti) from another area of the Kenyan Rift valley (Maskall \& Thornton, 1996). 
658 Additionally this was seen in moose (Alces gigas) in Alaska (Kubota, Rieger \& Lazar, 1970) and 659 several herbivores at the San Diego Wild Animal Park (USA) where hypocuprosis was 660 diagnosed, caused by feeding alfalfa with a high molybdenum (and sulphur) concentration 661 (Kubota, Rieger \& Lazar, 1970; Nelson, 1981; Maskall \& Thornton, 1996). In northeast 662 Zimbabwe, it was suggested that high concentrations of iron in the soil and forage inhibited the 663 availability of phosphorus to the plants, and thus to the cattle consuming the plants. The high 664 iron concentration in the soil also reduced the absorption of copper and zinc in cattle (Fordyce, 665 Masara \& Appleton, 1996).

666 Due to the ever-changing environment in which herbivores live, they are forced to make a series 667 of prioritised decisions to ensure survival. These decisions range from spatial to temporal and 668 vary in scale, from smaller scale decisions around which plant part to select for consumption, 669 through to decisions around seasonal movement patterns (Fryxell, 2008). De Knegt et al. (2011) 670 concluded that forage availability, both in terms of quantity and nutritional quality, varies 671 between seasons and years. Consequently those individual herbivores adapt their ranging 672 behaviour to meet their nutritional needs and ensure survival. This is especially important in 673 times of resource scarcity, where poor decision making may result in a reduced reproductive 674 output or death (Shannon et al., 2010). Appropriate discrimination between food items of high or 675 low quality can thus produce a selective advantage for long term survival (Fryxell, 2008).

676 From tracking data on 803 individuals of 57 species, Tucker et al. (2018) concluded that animal 677 movements are on average shorter in resource rich environments. For example red deer (Cervus 678 elaphus) in Slovenia were found to have reduced home ranges due to the enhancement of 679 resources, via supplementary feeding (Jerina, 2012), further agreeing with the work conducted 680 by Morellet et al. (2013) and Teitelbaum et al. (2015). Morellet et al. (2013) showed that the 681 home range of roe deer (Capreolus capreolus) at higher altitudes, was significantly larger than 682 roe deer at lower altitudes, despite forage availability at higher altitudes being more abundant 683 and of higher quality, although the growing season was shorter than at lower altitudes. This 684 suggested that home range, on an individual basis, is linked to a balance between metabolic 685 requirements and ability to acquire food, accounting for seasonal variation. Teitelbaum et al. 686 (2015) concluded from a review of 94 land migrations of 25 large herbivore species that there 687 was a ten-fold increase in the migration distance between resource high and low areas. These 
688 studies indicated that animals living in resource poor areas will have larger home ranges and 689 longer migration distances than those living in resource abundant areas.

690 African herbivores are not distributed heterogeneously. In the Serengeti National Park (SNP), 691 areas of high herbivore concentration corresponded with areas providing forages of higher 692 mineral content, implying that mineral content in foods was an important determinant of the 693 spatial distribution of herbivores within this park (McNaughton, 1988). For example, 694 magnesium, sodium and phosphorus had a particular influence on herbivore distribution, with 695 high herbivore density areas having 300\% more sodium, 50\% more phosphorus and 10-23\% 696 more magnesium, respectively, than low herbivore density areas. Secondly, migratory grazing 697 ungulate species in the SNP were reported to make seasonal movements based on grass mineral 698 content (McNaughton, 1990). Grasses, as is common in many tropical soils, were not sufficient 699 in magnesium and phosphorus to meet the mineral requirements for lactating and growing 700 ruminants, and overall were lower in minerals than grasses growing in temperate soils 701 (McDowell, 1985). The nutritional needs of lactating females and growing young were reported 702 to be influential on movement choices (McNaughton, 1990). Animals have evolved with 703 parturition periods being governed by the nutritional requirements of reproducing females and 704 growing young, seasonal rainfall and distance from forage of sufficient quality being prioritised 705 (McNaughton, 1990).

706 Herbivores have responded to plant evolutionary development through exhibiting seasonal 707 habitat selection and a reported change in movement behaviour. This was shown by Shannon et 708 al. (2010), from examining ranging behaviours and broad scale decision making of wildebeest 709 (Connochaetes taurinus), Thomson's gazelle (Gazella thomsoni thomsoni), red deer (Cervus 710 elaphus), reindeer (Rangifer tarandus) and elk (Cervus canadensis). Zebra and wildebeest 711 around the Sabi Sands Reserve, South Africa were seen to move seasonally to habitat types 712 characterised by grass communities with a high proportion of nutritious species, and generally 713 increased level of grass diversity, rather than selecting a particularly nutritious species within a 714 broader habitat (Ben-Shahar \& Coe, 1992). Home range movement showed that diet composition 715 and habitat use of these animals was influenced by the availability of nitrogen and phosphorus in 716 grasses (Ben-Shahar \& Coe, 1992). 


\section{Conclusions}

718 Evidence-based values for mineral requirements of elephants remain undetermined. Suspected

719 deficiencies in local key minerals might force animals to make movement choices to obtain these

720 minerals. In African savanna elephants this behaviour has been reported, although there is a need

721 for further research. The latter might reveal correlation patterns which could aid conservation

722 managers in making informed decisions surrounding elephant movement, and the mitigation of

723 human-elephant conflict.

724 This review collates evidence to suggest that African savanna elephants (and other herbivores)

725 consider nutritional drivers as a factor in their movement choices. The reasons dictating an

726 animals' daily, seasonal and annual movement are considered to be multifactorial, with

727 availability of water, human activity, social behaviour and topography all playing a role

728 alongside nutrient availability, specifically mineral provision. Minerals are available to elephants

729 from plants, water and soil, and all contribute to meeting their, as yet, undetermined mineral

730 needs. There is a relationship between geochemistry and herbivore movement, respectively

731 mineral provision to the consumer, through consumption of plants, water and soil (through

732 geophagy). This relationship needs to be further explored to aid in predicting animal movement.

733 National Parks and fenced reserves may occupy marginalised land of poorer quality, which has

734 not been assigned to agriculture. The vast increase in land required from 2014 to 2050 for human

735 population growth and agriculture will lead to a further reduction in land available for herbivores

736 such as savanna elephants, and human-elephant conflict is predicted to increase (Nyhus, 2016).

737 Wide ranging, landscape-level movements made by terrestrial herbivores are increasingly

738 threatened globally (Wall et al., 2013). From a practical conservation perspective, there is limited

739 research on the impact mineral provision may have on prediction or mitigation of human-

740 elephant conflict, and how this could be used as a tool for conflict resolution.

\section{References}

742 Ayotte JB., Parker KL., Arocena JM., Gillingham MP. 2006. Chemical composition of lick soils:

743 Functions of soil ingestion by four ungulate species. Journal of Mammalogy 87:878-888.

744 DOI: $10.1644 / 06-M A M M-A-055 R 1.1$. 
746

747

$$
\text { of Ecology 20:123-136. DOI: 10.1111/j.1365-2028.1982.tb00282.x. }
$$

Barnes RF., Asika S., Asamoah-Boateng B. 1995. Timber, cocoa and crop-raiding elephants: a preliminary study from southern Ghana. Pachyderm 19:33-38.

Bax P., Sheldrick D. 1963. Some preliminary observations on the food of elephant in the Tsavo Royal National Park (east) of Kenya. East African Wildlife Journal 1:40-53. DOI: 10.1111/j.1365-2028.1963.tb00177.x.

Beekman JH., Prins H. 1989. Feeding Strategies of sedentary large herbivores in east Africa with emphasis on the African buffalo, Sycerus caffer. Journal of African Ecology 27:129-147. DOI: $10.1111 /$ j.1365-2028.1989.tb00937.x.

Begon M., Harper J., Townsend C. 1986. Ecology: Individuals, populations and communities.

Bell R. 1982. The effect of soil nutrient availability on community structure in African ecosystems. In: Ecology of Tropical Savannas. Springer, Berlin, Heidelberg, 193-216. DOI: 10.1007/978-3-642-68786-0_10.

Ben-Shahar R., Coe MJ. 1992. The relationships between soil factors, grass nutrients and the foraging behaviour of wildebeest and zebra. Oecologia 90:422-428. DOI: 10.1007/BF00317701.

Birkett PJ., Vanak AT., Muggeo VMR., Ferreira SM., Slotow R. 2012. Animal perception of seasonal thresholds: Changes in elephant movement in relation to rainfall patterns. PLoS ONE 7. DOI: 10.1371 journal.pone.0038363.

Blake S. 2002. The ecology of forest elephant distribution and its implications for conservation. University of Edinburgh.

Blanc J. 2008.Loxodonta africana. The IUCN Red List of Threatened Species. Available at http://www.iucnredlist.org/details/12392/0 (accessed May 24, 2018).

Bowell RJ., Ansah RK. 1994. Mineral status of soils and forage in the Mole National Park, Ghana and implications for wildlife nutrition. Environmental Geochemistry and Health 16:41-58. DOI: 10.1007/BF00209824. 
772 Bowell RJ., Warren A., Redmond I. 1996. Formation of cave salts and utilization by elephants in

773 Mount Elgon region, Kenya. Environmental Geochemistry and Health Geological:63-79.

774 Carneiro L., Faria A., Werneck G., Dierenfeld E. 2015. Evaluation of diets offered to elephants 775 in Brazilian zoos. In: Eleventh Conference on Zoo and Wildlife Nutrition, AZA Nutrition 776 Advisory Group, Portland, OR.

777

778

779

780

781

782

783

784

785

786

787

788

789

790

791

792

793

794

795

796

797

798

Chandrajith R., Kudavidanage E., Tobschall HJ., Dissanayake CB. 2009. Geochemical and mineralogical characteristics of elephant geophagic soils in Udawalawe National Park, Sri Lanka. Environmental Geochemistry and Health. DOI: 10.1007/s10653-008-9178-5.

Chiyo PI., Cochrane EP., Naughton L., Basuta GI. 2005. Temporal patterns of crop raiding by elephants: a response to changes in forage quality or crop availability? Journal of African Ecology 43:48-55.

Clauss M., Castell JC., Kienzle E., Schramel P., Dierenfeld ES., Flach EJ., Behlert O., Streich WJ., Hummel J., Hatt JM. 2007. Mineral absorption in the black rhinoceros (Diceros bicornis) as compared with the domestic horse. Journal of Animal Physiology and Animal Nutrition. DOI: 10.1111/j.1439-0396.2007.00692.x.

Clauss M., Kienzle E., Wiesner H. 2003. Feeding browse to large zoo herbivores: how much is "a lot", how much is 'sufficient'? In: Fidgett A, Clauss M, Ganslober U, Hatt J, Nikboer J eds. Zoo Animal Nutrition. Filander Verlag Furth, 17-25. DOI: 10.5167/uzh-3516.

Codron J., Lee-Thorp JA., Sponheimer M., Codron D., Grant RC., De Ruiter DJ. 2006. Elephant (Loxodonta africana) diets in Kruger National Park, South Africa: spatial and landscape differences. Journal of Mammalogy 87:27-34. DOI: 10.1644/05-MAMM-A-017R1.1.

Das A., Saini M., Katole S., Kullu SS., Swarup D., Sharma AK. 2015. Effect of feeding different levels of wheat roti on nutrient utilization and blood metabolite profile in semi-captive Asian elephants (Elephas maximus). Journal of Animal Physiology and Animal Nutrition 99:367-378. DOI: 10.1111/jpn.12200.

Dierenfeld E. 2008. Biology, medicine, and surgery of elephants. In: Fowler M, Mikota SK eds. Biology, medicine, and surgery of elephants. Wiley-Blackwell publishing,. DOI: 
800

801

802

803

804

805

806

807

808

809

810

811

812

813

814

815

816

817

818

819

820

821

822

823

824

Dolmia NM., Calenge C., Maillard D., Planton H. 2007. Preliminary observations of elephant (Loxodonta africana, Blumenbach) movements and home range in Zakouma National Park, Chad. African Journal of Ecology 45:594-598. DOI: 10.1111/j.1365-2028.2007.00777.x.

Dougall H., Sheldrick D. 1964. The chemical composition of a day's diet of an elephant. Journal of African Ecology 2:51-59. DOI: 10.1111/j.1365-2028.1964.tb00196.x.

Douglas-Hamilton I., Krink T., Vollrath F. 2005. Movements and corridors of African elephants in relation to protected areas. Naturwissenschaften 92:158-163. DOI: 10.1007/s00114-0040606-9.

Ellis R. 1990. Tannin-like substances in grass leaves. In Memoiris of the Botanical Suvey of South Africa, Vol 59, ed O.A Leistner Pretoria: National Botanical Institute, South Africa, page 80 .

Eltringham S. 1990. Wildlife carrying capacities in relation to human settlement. Koedoe 33.

Ensley, P.T., Anderson, M., Osborn, K., Bissonnette, S. and Deftos, L. 1994. Osteodystrophy in an orphan Asian elephant. Proc Amer Assoc Zoo Vets, Pittsburgh, Pennsylvania, pp. 12143.

Fordyce F., Masara D., Appleton JD. 1996. Stream sediment, soil and forage chemistry as indicators of cattle mineral status in northeast Zimbabwe. Geological Society, London, Special Publications 113:23-37. DOI: 10.1144/GSL.SP.1996.113.01.03.

Fryxell J. 2008. Predictive modelling of patch use by terrestrial herbivores. In: Prins H.H.T., Van Langevelde F. (Eds) Resource Ecology. Wageningen UR Frontis Series, vol 23. Springer, Dordrecht.

Gomide J., Noller C., Mott G., Conrad J., Hill D. 1969. Mineral composition of six tropical grasses as influenced by plant age and nitrogen fertilisation. Agronomy Journal 61:120123. DOI: 10.2134/agronj1969.00021962006100010040x.

Grant C., Meissner H., Schultheiss W. 1995. The nutritive value of veld as indicated by faecal 
825

826

827

828

829

830

831

832

833

834

835

836

837

838

839

840

841

842

843

844

845

846

847

848

849

850

phosphorus and nitrogen and its rela tion to the condition and movement of prominent ruminants during the 1992-1993 drought in the Kruger National Park. Koedoe 38:17-31. DOI: 10.4102/koedoe.v38i1.302.

Greyling MD. 2004. Sex and Age related distinctions in the feeding ecology of the African elephant, Loxodonta africana. Philosophy:209.

Guy P. 1975. The daily food intake of the African elephant, Loxodonta africana Blumenbach in Rhodesia. Arnoldia 7:1-8.

Hoare R. 1999. Determinants of human-elephant conflict in a land-use mosaic. Journal of Applied Ecology 36:689-700.

Hoare R. 2000. African elephants and humans in conflict: The outlook for co-existence. Oryx 34:34-38. DOI: 10.1046/j.1365-3008.2000.00092.x.

Hoare R., du Toit J. 1999. Coexistence between people and elephants in African savannas. Conservation Biology 13:633-639. DOI: 10.1046/j.1523-1739.1999.98035.x.

Holdø R., Dudley J., McDowell L. 2002. Geophagy in the African elephant in relation to availability of dietary sodium. Journal of Mammalogy 83:652-664. DOI: 10.1644/15451542.

Holdø RM., McDowell LR. 2004. Termite mounds as nutrient-rich food patches for elephants. Biotropica 36:231-239. DOI: 10.1111/j.1744-7429.2004.tb00314.x.

Holechek J., Galyean M., Wallace J., Wofford H. 1985. Evaluation of faecal indices for predicting phosphorus status in cattle. Grass and Forage Science 40:489-492. DOI: 10.1111/j.1365-2494.1985.tb01782.x.

Humphrey OS., Young SD., Bailey EH., Crout NMJ., Ander EL., Watts MJ. 2018. Iodine soil dynamics and methods of measurement: a review. Environmental Science: Processes \& Impacts. DOI: 10.1039/C7EM00491E.

Hurst R., Siyame EWP., Young SD., Chilimba ADC., Joy EJM., Black CR., Ander EL., Watts MJ., Chilima B., Gondwe J., Kang’ombe D., Stein AJ., Fairweather-tait SJ., Gibson RS., 
851

852

853

854

855

856

857

858

859

860

861

862

863

864

865

866

867

868

869

870

871

872

873

874

875

876

877

Kalimbira AA., Broadley MR., Kang D., Kang 'ombe D., Stein AJ., Fairweather-tait SJ., Gibson RS., Kalimbira AA., Broadley MR. 2013. Soil-type influences human selenium status and underlies widespread selenium deficiency risks in Malawi. Scientific reports 3:1425. DOI: $10.1038 /$ srep01425.

Jachmann H. 1989. Food selection by elephants in the "Miombo" biome, in relation to leaf chemistry. Biochemical Systematics and Ecology 17:15-24. DOI: 10.1016/03051978(89)90037-9.

Jachmann H., Bell R. 1985. Utilization by elephants of the Brachystegia woodlands of the Kasungu National Park, Malawi. Journal of African Ecology 23:245-258. DOI: 10.1111/j.1365-2028.1985.tb00955.x.

Jerina K. 2012. Roads and supplemental feeding affect home-range size of Slovenian red deer more than natural factors. Journal of Mammalogy. DOI: 10.1644/11-MAMM-A-136.1.

Joy E., Broadley M., Young S., Black C., Chilimba A., Ander L., Barlow T., Watts M. 2015. Soil type influences crop mineral composition in Malawi. Science of the Total Environment, The 505:587-595. DOI: 10.1016/j.scitotenv.2014.10.038.

Kabigumila J. 1993. Feeding habits of elephants in Ngorongoro Crater, Tanzania. Journal of African Ecology 31:156-164. DOI: 10.1111/j.1365-2028.1993.tb00528.x.

Kalumanga E., Mpanduji D., Cousins S. 2017. Geophagic termite mounds as one of the resources for African elephants in Ugalla Game Reserve, Western Tanzania. African Journal of Ecology. DOI: 10.1111/aje.12326.

Klaus G., Schmidg B. 1998. Geophagy at natural licks and mammal ecology: A review. Mammalia 64:482-498.

de Knegt H., Van Langevelde F., Skidmore A., Delsink A., Slotow R., Henley S., Bucini G., De Boer W., Coughenour M., Grant C., Heitkönig I., Henley M., Knox N., Kohi E., Mwakiwa E., Page B., Peel M., Pretorius Y., Van Wieren S., Prins H. 2011. The spatial scaling of habitat selection by African elephants. Journal of Animal Ecology 80:270-281. DOI: 10.1111/j.1365-2656.2010.01764.x. 
878 van der Kolk J., van Leeuwen J., van den Belt A., van Schaik R., Schaftenaar W. 2008.

879 Subclinical hypocalcaemia in captive elephants (Elephas maximus). Veterinary record 880 162:475-479. DOI: $10.1136 /$ vr.162.15.475.

881 Kubota J., Rieger S., Lazar A. 1970. Mineral composition of herbage browsed by moose in 882 Alaska. The Journal of Wildlife Management 34:565-569. DOI: 10.2307/3798864.

883 Laws R. 1970. Elephants and habitats in North Bunyoro Uganda. Journal of African Ecology 884 8:163-180. DOI: 10.1111/j.1365-2028.1970.tb00838.x.

885 886

887

888

889

890

891

892

893

894

895

896

897

898

899

900

901

902

903

Lawson GW., Jenik J., Armstrong Mensah KO. 1968. A study of a vegetation catena in Guinea savanna at Mole Game Reserve Ghana. Journal of Ecology 56:505-522. DOI: $10.2307 / 2258248$

Leggett K. 2015. Home range and seasonal movement of elephants in the Kunene Region, northwestern Namibia. African Zoology 41:17-36. DOI: 10.1080/15627020.2006.11407332.

Maskall J., Thornton I. 1996. The distribution of trace and major elements in Kenyan soil profiles and implications for wildlife nutrition. Geological Society, London, Special Publications 113:47-62. DOI: 10.1144/GSL.SP.1996.113.01.05.

McCullagh K. 1969. The growth and nutrition of the African elephant I. Seasonal variations in the rate of growth and the urinary excretion of hydroxyproline. African Journal of Ecology 7:85-90. DOI: 10.1111/j.1365-2028.1969.tb01196.x.

McNaughton S. 1988. Mineral nutrition and spatial concentrations of African ungulates. Nature 334:343-345. DOI: 10.1038/334343a0.

McNaughton S. 1990. Mineral nutrition and seasonal movements of African migratory ungulates. Nature 345:613-615.

Meissner HH., Spreeth EB., Villiers PA De., Pietersen EW., Hugo TA., Terblanche BF. 1990. Quality of food and voluntary intake by elephant as measured by lignin index. South African Journal of Wildlife Research 20:104-110. 
904 Michell A. 1995. The clinical biology of Sodium: the physiology and pathophysiology of Sodium 905 in mammals. Pergamon, Elsevier, page 105-122. DOI: 10.1016/C2013-0-00720-7.

906 Milewski A. 2000. Iodine as possible controlling nutrient. Pachyderm 28:78-90.

907 Milewski A V., Dierenfeld ES. 2012. Supplemental iodine as a key to reproduction in pandas? 908 Integrative Zoology 7:175-182. DOI: 10.1111/j.1749-4877.2012.00283.x.

909 Morellet N., Bonenfant C., Börger L., Ossi F., Cagnacci F., Heurich M., Kjellander P., Linnell 910 JDC., Nicoloso S., Sustr P., Urbano F., Mysterud A. 2013. Seasonality, weather and climate 911 affect home range size in roe deer across a wide latitudinal gradient within Europe. Journal 912 of Animal Ecology 82:132-139. DOI: 10.1111/1365-2656.12105.

913

914

915

916

917

918

919

920

921

922

923

924

925

926

927

928

929

930

Muvengwi J., Mbiba M., Nyenda T. 2013. Termite mounds may not be foraging hotspots for mega-herbivores in a nutrient-rich matrix. Journal of Tropical Ecology 29:551-558. DOI: $10.1017 / \mathrm{S} 0266467413000564$.

Muvengwi J., Ndagurwa H., Nyenda T., Mlambo I. 2014. Termitaria as preferred browsing patches for black rhinoceros (Diceros bicornis) in Chipinge Safari Area, Zimbabwe. Journal of Tropical Ecology 30:51-598. DOI: 10.1017/S0266467414000480.

Mwangi P., Milewski A., Wahungu G. 2004. Chemical compsition of mineral licks used by elephants in Aberdaes National Park, Kenya. Pachyderm 37:59-67.

\section{National Research Council. 1989. Nutrient requirements of horses: Fifth revised edition.} Washington, DC: The National Academies Press. doi.org/10.17226/1213.

Naughton-Treves L. 2008. Predicting patterns of crop damage by wildlife around Kibale National Park, Uganda. Conservation Biology 12.

Nellemann C., Moe SR., Rutina LP. 2002. Links between terrain characteristics and forage patterns of elephants (Loxodonta africana) in northern Botswana. Journal of Tropical Ecology 18:835-844. DOI: 10.1017/S0266467402002547.

Nelson L. 1981. Secondry hypocuprosis in an exotic animal park. San Diego.

Nyhus PJ. 2016. Human-Wildlife conflict and coexistence. DOI: 10.1146/annurev-environ110615-085634. 
931 Olson D. 2004.Elephant Husbandry Resource Guide. Available at

932 http://www.elephantconservation.org/iefImages/2015/06/CompleteHusbandryGuide1stEditi

933 on.pdf (accessed June 1, 2018).

934 Osborn F V. 2004. Seasonal variation of feeding patterns and food selection by crop-raiding

935 elephants in Zimbabwe. african Journal of Ecology:322-327.

936 Partington C. 2012. Feeding, nutrition and body condition of UK elephants. University of

$937 \quad$ Liverpool.

938 Pretorius Y., de Boer F., van der Waal C., de Knegt H., Grant R., Knox N., Kohi E., Mwakiwa

939 E., Page B., Peel MJ., Skidmore A., Slotow R., van Wieren S., Prins H. 2011. Soil nutrient

940 status determines how elephant utilize trees and shape environments. Journal of Animal

941 Ecology 80:875-883. DOI: 10.1111/j.1365-2656.2011.01819.x.

942 Pretorius Y., Stigter JD., de Boer WF., van Wieren SE., de Jong CB., de Knegt HJ., Grant CC.,

943 Heitkönig I., Knox N., Kohi E., Mwakiwa E., Peel MJS., Skidmore AK., Slotow R., van der

944 Waal C., van Langevelde F., Prins HHT. 2012. Diet selection of African elephant over time

945 shows changing optimization currency. Oikos 121:2110-2120.

946 Rode K., Chiyo P., Chapman C., McDowell L. 2006. Nutritional ecology of elephants in Kibale

947 National Park, Uganda, and its relationship with crop-raiding behaviour. Journal of

948 Tropical Ecology 22:441. DOI: 10.1017/S0266467406003233.

949 Said M., Chunge R., Craig G., Thouless C., Barnes RF., Dublin H. 1995. The African elephant $950 \quad$ database. IUCN/SSC Occasional Paper 11.

951 Sayers A. 2007. Tips and tricks in performing a systematic review. The British Journal of 952 General Practice 57:425.

953 Schmidt M. 1989. Zinc deficiency, presumptive secondary immune deficiency and

954 hyperkeratosis in an Asian elephant: A case report. In: American Association of Zoo Vets. $955 \quad 23-31$.

956 Shannon G., Page B., Mackay R., Duffy K., Slotow R. 2008. Activity Budgets and Sexual 957 Segregation in African Elephants (Loxodonta africana). Journal of Mammalogy 89:467- 
959 Shetaya W., Young S., Watts M., Ander L., Bailey E. 2012. Iodine dynamics in soils. 960 Geochimica et Cosmochimica Acta 77:457-473. DOI: 10.1016/j.gca.2011.10.034.

961 Sienne JM., Buchwald R., Wittemyer G. 2014. Differentiation in mineral constituents in elephant 962 selected versus unselected water and soil resources at Central African bais (forest

963

964 clearings). European Journal of Wildlife Research 60:377-382. DOI: 10.1007/s10344-0130781-0.

965

966

967

968

969

970

971

972

973

974

975

976

977

978

979

980

981

982

983

984

Stokke S., Du Toit JT. 2002. Sexual segregation in habitat use by elephants in Chobe National Park, Botswana. African Journal of Ecology. DOI: 10.1046/j.1365-2028.2002.00395.x.

Sukumar R. 1990. Ecology of the Asian elephant in southern India. II. Feeding habits and crop raiding Patterns. Journal of Tropical Ecology 6:33-53. DOI: 10.2307/2559367.

Sutton P., Maskall J., Thornton I. 2002. Concentrations of major and trace elements in soil and grass at Shimba Hills National Reserve, Kenya. Applied Geochemistry 17:1003-1016. DOI: 10.1016/S0883-2927(02)00056-2.

Tangley L. 1997. In search of Africa's forgotten forest elephant. Science 275:1417-1419. DOI: 10.1126/science.275.5305.1417.

Teitelbaum C., Fagan W., Fleming C., Dressler G., Calabrese JM., Leimgruber P., Mueller T. 2015. How far to go?: Determinants of migration distance in land mammals. Ecology Letters 18:545-552. DOI: 10.1111/ele.12435.

Thomas B., Holland J., Minot E. 2008. Elephant (Loxodonta africana) home ranges in Sabi Sand reserve and Kruger National Park: A Five-year satellite tracking study. PLoS ONE 3. DOI: 10.1371/journal.pone.0003902.

Tucker MA., Böhning-Gaese K., Fagan WF., Fryxell JM., Van Moorter B., Alberts SC., Ali AH., Allen AM., Attias N., Avgar T., Bartlam-Brooks H., Bayarbaatar B., Belant JL., Bertassoni A., Beyer D., Bidner L., van Beest FM., Blake S., Blaum N., Bracis C., Calabrese JM., Ford AT., Fritz SA., Gehr B., Goheen JR., Hof C., Hurme E., Kaczensky P., Kane A., Kappeler PM., Kauffman M., Leimgruber P., C Linnell JD., López-López P., Catherine Markham A., 
985

986

987

988

989

990

991

992

993

994

995

996

997

998

999

1000

1001

1002

1003

1004

1005

1006

1007

1008

1009

1010

1011

Morato RG., Morellet N., Morrison TA., Nandintsetseg D., Nathan R., Niamir A., Odden J., O RB., Gustavo Oliveira-Santos LR., Olson KA., Patterson BD., Rimmler M., Rogers TL., Moe Rolandsen C., Rosenberry CS., Zięba F., Zwijacz-Kozica T., Mueller T. 2018. Moving in the Anthropocene: Global reductions in terrestrial mammalian movements. Science 359:466-469. DOI: 10.1126/science.aam9712.

Ullrey D., Crissey S., Hintz H. 1997. Elephants: nutrition and dietary husbandry. In: Allen M, Edwards M, Roocroft A eds. Nutrition Advisory Group Handbook. 1-20.

Underwood E. 1977. Trace elements in human and animal nutrition. Academic Press.

de Villiers P., Pietersen E., Hugo T., Meissner H., Kok O. 1991. Method of sampling food consumption by free-ranging elephant. South African Journal of Wildlife Research 21:2327.

Wall J., Douglas-Hamilton I., Vollrath F. 2006. Elephants avoid costly mountaineering. Current Biology. DOI: 10.1016/j.cub.2006.06.049.

Wall J., Wittemyer G., Klinkenberg B., LeMay V., Douglas-Hamilton I. 2013. Characterizing properties and drivers of long distance movements by elephants (Loxodonta africana) in the Gourma, Mali. Biological Conservation. DOI: 10.1016/j.biocon.2012.07.019.

Walter O. 2010. BIAZA Elephant Management Guidelines for the Welfare of Zoo Animals - 3rd Edition. DOI: e.T12392A3339343.

Watts MJ., Joy EJM., Young SD., Broadley MR., Chilimba ADC., Gibson RS., Siyame EWP., Kalimbira AA., Chilima B., Ander EL. 2015. Iodine source apportionment in the Malawian diet. Scientific Reports. DOI: 10.1038/srep15251.

Weir JS. 1969. Chemical properties and occurrence on Kalahari sand of salt licks created by elephants. Journal of Zoology 158:293-310.

Weir JS. 1972. Spatial Distribution of Elephants in an African national park in relation to environmental sodium. Oikos 23:1-13.

Western D., Lindsay W. 1984. Seasonal herd dynamics of a savanna elephant population. African Journal of Ecology 22:229-244. DOI: 10.1111/j.1365-2028.1984.tb00699.x. 
1012 Whitehouse A., Schoeman D. 2003. Ranging behaviour of elephants within a small, fenced area 1013 in Addo Elephant National Park, South Africa. African Zoology 38:95-108. DOI:

1014 10.1080/15627020.2003.11657197.

1015 Williamson B. 1975. The condition and nutrition of elephant in Wankie National Park. Arnoldia $1016 \quad$ Rhodesia 7:1-20.

1017 Wing, L D., Buss, I E. 1970. Elephants and forest. Wildlife Monographs 19:1-92.

1018 Wrench J., Meissner H., Grant C. 1997. Assessing diet quality of African ungulates from faecal 1019 analyses: the effect of forage quality, intake and herbivore species. Koedoe 40:125-136.

1020 DOI: $10.4102 /$ koedoe.v40i1.268.

1021 Wu Z., Satter L., Sojo R. 2000. Milk production, reproductive performance, and fecal excretion 1022 of phosphorus by dairy cows fed three amounts of phosphorus. Journal of Dairy Science 83:1028-1041. DOI: 10.3168/jds.S0022-0302(00)74967-8.

1024

1025 


\section{Figure 1 (on next page)}

Breakdown of the literature by date after the application of the inclusion/exclusion criteria 


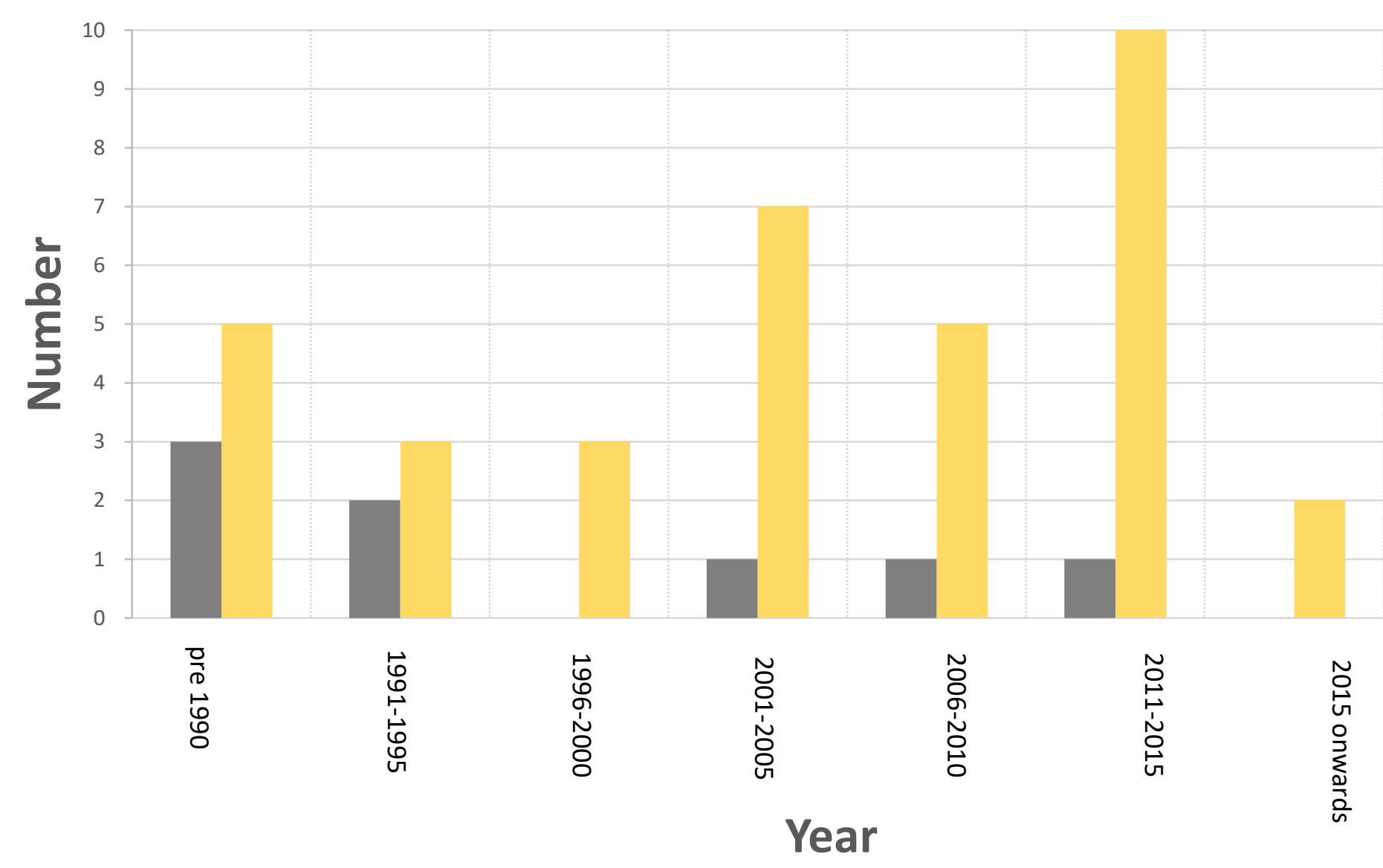

- Grey literature

Peer reviewed literature 


\section{Table $\mathbf{1}$ (on next page)}

Macro-mineral concentrations (\%dry matter) in native plants consumed by African elephants (Loxodonta africana) in southern and eastern Africa

Mineral levels in various southern and eastern african plant parts 


\begin{tabular}{|c|c|c|c|c|c|c|c|}
\hline Location & Season & Plant part & Calcium & Phosphorus & Magnesium & Sodium & Source \\
\hline \multirow{7}{*}{$\begin{array}{l}\text { Hwange } \\
\text { National } \\
\text { Park, } \\
\text { Zimbabwe }\end{array}$} & \multirow{5}{*}{ unknown } & Mature & $0.02-$ & & $0.08-0.64$ & $0.02-$ & \multirow{5}{*}{$\begin{array}{l}\text { (Holdø, } \\
\text { Dudley \& } \\
\text { McDowell, } \\
\text { 2002) }\end{array}$} \\
\hline & & $\begin{array}{l}\text { leaves } \\
\text { Young }\end{array}$ & $\begin{array}{l}3.12 \\
0.01-\end{array}$ & & & $\begin{array}{l}0.06 \\
0.005-\end{array}$ & \\
\hline & & leaves & 1.32 & & $0.1-0.57$ & 0.05 & \\
\hline & & $\begin{array}{l}\text { Stems, } \\
\text { twigs }\end{array}$ & $\begin{array}{l}0.11- \\
1.85\end{array}$ & & $0.02-0.20$ & $\begin{array}{l}0.001- \\
0.02\end{array}$ & \\
\hline & & Bark & $\begin{array}{l}0.13- \\
3.93\end{array}$ & & $0.01-0.33$ & $\begin{array}{l}<0.001- \\
0.02\end{array}$ & \\
\hline & \multirow{2}{*}{$\begin{array}{l}\text { End wet } \\
\text { season }\end{array}$} & Browse & $\begin{array}{l}0.35- \\
2.47\end{array}$ & $0.11-0.33$ & & & \multirow{2}{*}{$\begin{array}{l}\text { (Williamson, } \\
1975 \text { ) }\end{array}$} \\
\hline & & Grass & $\begin{array}{l}0.41- \\
0.66\end{array}$ & $0.09-0.20$ & & & \\
\hline $\begin{array}{l}\text { Kasungu } \\
\text { National } \\
\text { Park, } \\
\text { Malawi }\end{array}$ & unknown & $\begin{array}{l}\text { Tree leaves } \\
\text { (12 sp.) }\end{array}$ & & & & $\begin{array}{l}0.10- \\
1.25\end{array}$ & $\begin{array}{l}\text { (Jachmann } \\
\text { \& Bell, } \\
\text { 1985) }\end{array}$ \\
\hline \multirow{5}{*}{$\begin{array}{l}\text { Tsavo } \\
\text { National } \\
\text { Park, } \\
\text { Kenya }\end{array}$} & unknown & $\begin{array}{l}\text { Grass and } \\
\text { browse (59 } \\
\text { sp.) }\end{array}$ & $\begin{array}{l}0.37- \\
3.61\end{array}$ & $0.08-0.36$ & & $\begin{array}{l}0.01- \\
1.67\end{array}$ & $\begin{array}{l}\text { (Dougall \& } \\
\text { Sheldrick, } \\
\text { 1964) }\end{array}$ \\
\hline & $\begin{array}{l}\text { Wet } \\
\text { season }\end{array}$ & Mixed & $\begin{array}{l}0.13- \\
0.38\end{array}$ & & & & \multirow{4}{*}{$\begin{array}{l}\text { (McCullagh, } \\
\text { 1969a) }\end{array}$} \\
\hline & $\begin{array}{l}\text { Dry } \\
\text { season }\end{array}$ & plant sp. & 0.38 & & & & \\
\hline & \multirow[t]{2}{*}{ unknown } & $\begin{array}{l}\text { Grasses } \\
\text { and herb } \\
\text { type } \\
\text { vegetation }\end{array}$ & $\begin{array}{l}0.36- \\
1.44\end{array}$ & & & & \\
\hline & & shrub & $\begin{array}{l}0.53- \\
8.92\end{array}$ & & & & \\
\hline
\end{tabular}




\section{Table 2 (on next page)}

Reported dietary mineral recommendations for African elephants (Loxodonta africana)

Estimated mineral requirements for African elephants 


\begin{tabular}{|l|l|l|l|l|}
\hline Mineral & Species & Detail & $\begin{array}{l}\text { Daily Estimated } \\
\text { Mineral } \\
\text { Requirements }\end{array}$ & Source \\
\hline Calcium & L. africana & $\begin{array}{l}\text { Lactating females } \\
\text { Intensive tusk } \\
\text { growth }\end{array}$ & $\begin{array}{l}60 \mathrm{~g} \\
8-9 \mathrm{~g}\end{array}$ & $\begin{array}{l}\text { (McCullagh, 1969; } \\
\text { Dierenfeld, 2008) }\end{array}$ \\
\hline Sodium & L. africana & & $9 \mathrm{mg} \mathrm{Na} \mathrm{kg}^{-1} \mathrm{BW}$ & $\begin{array}{l}\text { (Holdø, Dudley \& } \\
\text { McDowell, 2002) }\end{array}$ \\
\hline Iodine & L. africana & & $0.03 \mathrm{mg} \mathrm{I} \mathrm{kg}^{-1} \mathrm{BW}$ & (Milewski, 2000) \\
\hline
\end{tabular}

